\title{
Aberrant expression of Class II major histocompatibility complex molecules by $B$ cells and hyperexpression of Class I major histocompatibility complex molecules by insulin containing islets in Type 1 (insulin-dependent) diabetes mellitus
}

\author{
A. K. Foulis, M. A. Farquharson and R. Hardman \\ University Department of Pathology, Royal Infirmary, Glasgow, UK
}

\begin{abstract}
Summary. Twenty-three patients with recent onset Type 1 (insulin-dependent) diabetes in whom residual insulin secreting B cells were present and 12 patients with disease of more prolonged duration (maximum 9 years), 8 of whom had residual B cells, were studied. Aberrant expression of Class II major histocompatibility complex molecules was demonstrated immunohistochemically on insulin secreting B cells in 21 out of 23 patients with recent onset disease and 6 of the patients with more prolonged disease. No such expression was seen on glucagon secreting A cells or somatostatin secreting D cells. Islets where there was marked hyperexpression of Class I major histocompatibility complex molecules on islet endocrine cells were seen in all cases in which residual B cells were present. Ninety-two per cent of insulin containing islets but only $1 \%$ of insulin deficient islets exhibited
\end{abstract}

this phenomenon ( $p<0.001$, Chi-squared test). There was evidence to suggest that both these abnormalities of major histocompatibility complex expression preceded insulitis within a given islet. They also appeared to be unique to Type 1 diabetes, being absent in pancreases of patients with Type 2 (non-insulin-dependent) diabetes, chronic pancreatitis, cystic fibrosis, graft-versus-host disease and Coxsackie B viral pancreatitis. The development of autoimmunity to B cells in Type 1 diabetes may be a "multistep" process in which abnormalities of major histocompatibility complex expression on islet endocrine cells are crucial events.

Key words: Pancreas, islets of Langerhans, antigen-immune response, autoimmunity, Type 1 diabetes mellitus, major histocompatibility complex.
Two factors are recognised to be involved in the pathogenesis of Type 1 (insulin-dependent) diabetes. Firstly, there is considerable evidence that the disease is an example of an organ-specific autoimmune disease in which the insulin secreting $B$ cells are destroyed by an inflammatory cell infiltrate affecting the islets [1-3]. Secondly, there is a marked genetic component to the risk of acquiring the disease which is linked to Class II major histocompatibility complex (MHC) genes (HLA-DP - DQ and - DR in man). Thus, up to $98 \%$ of all patients with Type 1 diabetes possess either DR3 or DR4 genes [4].

It is thought that the principal function of Class II MHC products is to facilitate antigen presentation. $T$ helper lymphocytes, which will initiate an immune response, only recognise the antigen to which they are directed if it is 'presented' to them by a cell expressing the same Class II MHC as themselves. It has been proposed that the initial event in many organ-specific autoimmune diseases may be aberrant expression of Class II MHC by the target cells [5]. If a cell did not normally express Class II MHC on its surface, then any cell specific auto-antigens it may possess would never have been 'presented' to potentially autoreactive $T$ helper lymphocytes. Thus, even though the latter may exist, there would be no immune response. If however, the cell were induced to express Class II MHC, then it may become a functional antigen presenting cell. It may then "present" its particular cell surface antigen to potentially autoreactive $T$ helper lymphocytes, which would then initiate an autoimmune response. This hypothesis is particularly attractive because it encompasses the agent linked to the genetic predisposition to Type 1 diabetes - DR type with an event on the target cell, i.e. aberrant expression of Class II MHC.

Endocrine cells in the normal pancreas do not express Class II MHC [6,7]. In the pancreas in Type 1 diabetes only the $\mathrm{B}$ cells are destroyed $[3,8]$. Thus, if the hypothesis were valid in this disease, only the B cells would aberrantly express Class II MHC. Expression of Class II MHC products, confined to B cells, was initially reported in a single case of recent onset Type 1 diabetes where fresh frozen autopsy pancreas 
was available [9]. Recently, with the advent of the monoclonal antibody TAL-1B5, which is capable of detecting a formalin resistant epitope of the alpha-chain of HLA-D molecules [10, 11], expression of Class II MHC on B cells was seen in pancreases from 12 patients with Type 1 diabetes [12]. All other endocrine cells were negative, and no aberrant expression was seen on B cells in Type 2 diabetes, cystic fibrosis or chronic pancreatitis [12].

A second abnormality of MHC expression has been observed in the pancreas in Type 1 diabetes. Bottazzo et al. [9] reported that there was marked hyperexpression of Class I MHC (HLA-A-B and $-C$ in man) on endocrine cells in some islets. This phenomenon was not fully characterised, and in particular no mention was made of the types of endocrine cell affected.

The aims of the present report were to study these abnormalities of MHC expression in a large number of patients with Type 1 diabetes in an attempt to establish firstly, whether they were unique to the disease, and secondly, whether they were purely the result of inflammation within the islets or whether they occurred independently of the presence of insulitis.

\section{Subjects and methods}

The pancreases of 35 patients who had died with Type 1 diabetes in whom the pancreatic histopathology was "classical" [3] were studied. This included all 14 cases which were reported previously [12]. Twelve patients had had diabetes for more than 1 year (maximum 9 years). Cases of prolonged duration diabetes were selected to include those in whom residual B cells were present. Twenty-three patients had died within a few weeks of onset of symptoms. Four of these patients had evidence of other autoimmune diseases ("polyendocrine diabetes"); two patients had thyrotoxicosis and two Addison's disease.

Pancreases from the following were also included as controls: (1) Thirty-eight autopsies on children who had died of a variety of conditions but in whom the pancreas was histologically normal. (2) Twenty patients who had died after receiving total body irradiation and bone marrow grafting as therapy for leukaemia (fifteen of these patients died with significant graft-versus-host disease). (3) Five pancreatic resections for chronic pancreatitis. (4) Autopsies on 10 children who had died of cystic fibrosis. (5) Autopsies on 10 patients who had Type 2 (non-insulin-dependent) diabetes. (6) Autopsies on 12 neonates who had died of culture proven Coxsackie B viral myocarditis.

All the tissues studied had been fixed in either buffered formalin or formol saline with or without added mercuric chloride. Four micron serial sections were cut from the paraffin embedded blocks of the pancreases from patients with Type 1 diabetes, those with Coxsackie $B$ virus infection and those who had had marrow transplants. Adjacent serial sections from these cases, and three nonserial sections from all others, were stained with an indirect immunoperoxidase technique in which diaminobenzidine was the substrate, using the following primary polyclonal antisera: rabbit anti-Class I MHC heavy chain ("AI", gift from J.J. Neefjes, Amsterdam, The Netherlands), guinea pig anti-insulin (Wellcome, Dartford, UK) and rabbit anti-Class II MHC ("AII", gift from J.J. Neefjes). A minority of the Type 1 diabetic pancreases were stained using the same techniques with two other primary polyclonal antisera: rabbit anti-beta-2-microglobulin (Dako, High Wycombe, UK) and a second rabbit antiClass II MHC ("UUII", gift from L. Klareskog, Uppsala, Sweden).
These latter two antisera were tested to confirm the findings using the antisera AI and AII. The following bridges for the indirect techniques were used: peroxidase conjugated rabbit anti-guinea pig, swine anti-rabbit and rabbit anti-mouse immunoglobulins (all Dako). In addition to the sections described, one pancreatic block from each of 3 cases [Case 8 (total number of blocks 3), Case 12 (total number of blocks 6) and Case 19 (total number of blocks 4); Table 1] was selected and $404-\mu \mathrm{m}$ serial sections cut. The middle two sections of these series were stained for Class I MHC (using antiserum $\mathrm{AI}$ ) and insulin respectively. The remaining sections were all stained for Class II MHC (using antiserum AII). Insulin containing islets were identified on the section stained for insulin and the presence or absence of hyperexpression of Class I MHC and aberrant expression of Class II MHC noted by viewing each islet on the remaining serial sections. Over $90 \%$ of the insulin containing islets identified were assessed in each of these cases.

Detailed studies of the specificity of these various antisera have been published. The rabbit antiserum to Class I MHC, AI, was prepared against a mixture of purified heavy chains of HLA-B7 and HLA-B40 (13). In an immunoblot analysis of white cells from 21 different HLA blood type donors this antiserum reacted with all the HLA-B locus specificities tested, in addition to a number of A-locus products. An indirect way of looking at Class I MHC expression in tissue is to study the distribution of beta-2-microglobulin. This protein, which is coded for by a gene on a different chromosome from that which codes for Class I MHC, associates non-covalently with Class I MHC in the plasma membrane [14]. Thus, in addition to studying Class I MHC expression in the diabetic pancreases, the distribution of beta-2-microglobulin was also examined in an attempt to confirm the results. The distribution of immunoperoxidase staining on formalin fixed pancreas and tonsil using the antiserum $\mathrm{AI}$ and the antiserum to beta-2-microglobulin as primary antisera was compared to staining on fresh frozen pancreas and tonsil using the same antisera, and also the mouse monoclonal antibody W6/32 (Sera-Lab, Sussex, UK) which recognises all HLA-A and $-B$ antigens [15]. The staining patterns were identical.

The rabbit antiserum, AII, was raised against the purified human Class II antigens, DR and DQ [16]. Part of the antigen had been denatured by heat. The serum recognised human Class II alpha chains and a number of Class II beta chains in immunoblot analysis, and it reacted with $D P, D Q$ and $D R$. The specificity of the second antiClass II MHC antiserum (UUII) has also been previously described in detail [17]. The staining patterns using immunohistochemistry on formalin fixed pancreas and lymph node with these two antisera, and the mouse monoclonal antibody TAL-1B5 (directed against HLA-D region alpha chains [10] were compared with their staining on fresh frozen pancreas and lymph node. The staining was identical in all cases.

All the rabbit antisera to MHC molecules and beta-2-microglobulin performed satisfactorily with the immunoperoxidase techniques on tissue fixed in any of the commonly used fixatives. When normal rabbit serum was substituted for these antisera in an indirect immunoperoxidase technique, no staining of any description was seen on either diabetic or normal pancreases.

Double staining techniques were developed to show which hormone producing cells expressed Class II MHC or hyperexpressed Class I MHC. Following an overnight incubation at $4^{\circ} \mathrm{C}$ with either AI or AII, the sections were incubated with peroxidase conjugated swine anti-rabbit immunoglobulins for $30 \mathrm{~min}$ at room temperature. The reaction was developed using diaminobenzidine as substrate. Double staining for insulin was done using a subsequent 4-h incubation of the guinea pig anti-insulin anti-serum followed by a $30-\mathrm{min}$ incubation in rabbit anti-guinea pig immunoglobulins (Dako). Finally, there was a $30 \mathrm{~min}$ incubation with fluorescein conjugated donkey anti-rabbit immunoglobulins (Scottish Antibody Production Unit, Carluke, UK). Repeated washings were done between steps using tris buffered saline. Double staining for Class I and II MHC and other pancreatic hormones utilised the same method up to the development with diaminobenzidine. This was followed by a 15-min incubation in normal swine serum, a 4-h incubation with either rabbit anti-glucagon (Guildhay, Guildford, UK) or rabbit anti-somatostatin 

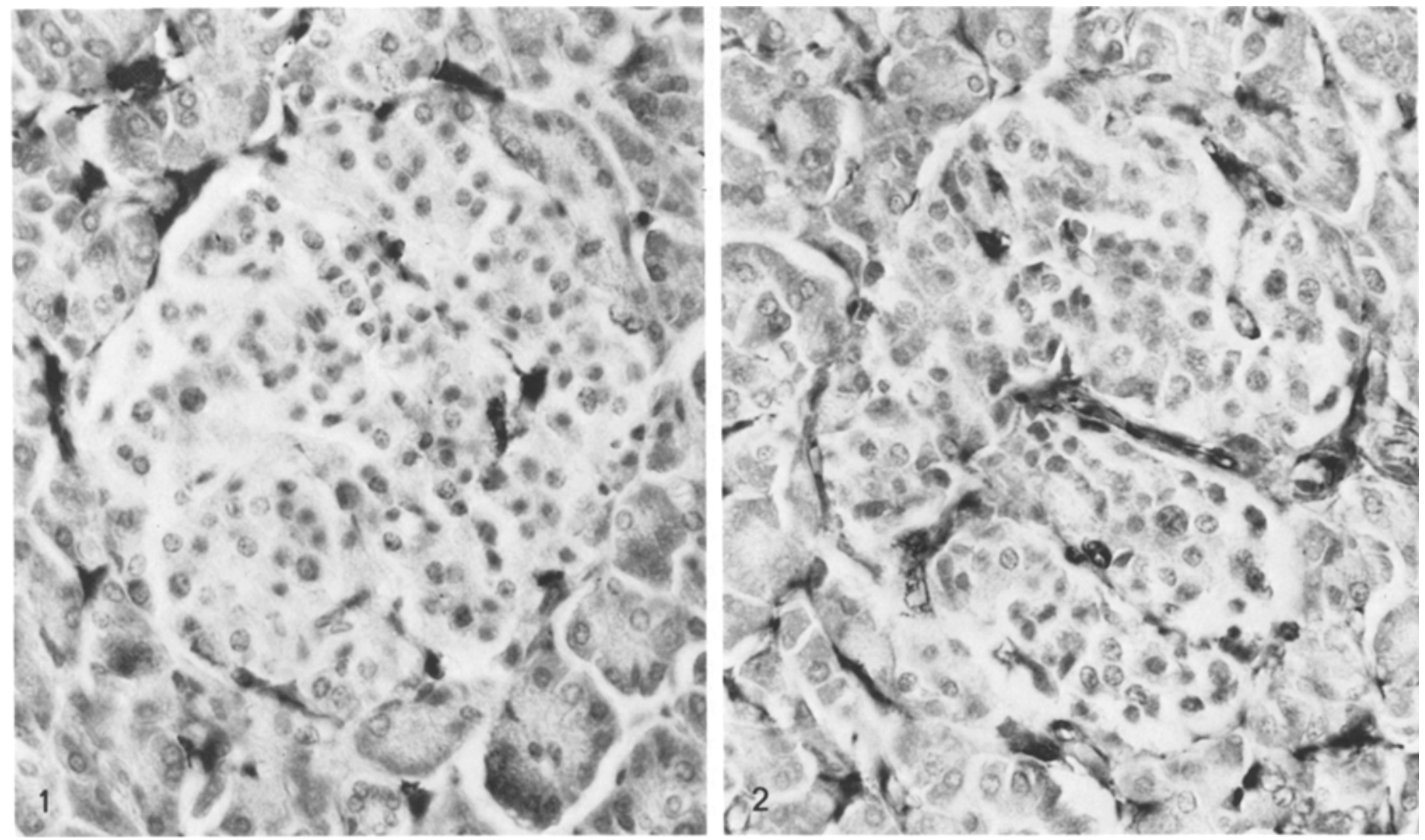

Fig. 1. Class II MHC expression in normal autopsy pancreas. Only the endothelial cells are positive. (Indirect immunoperoxidase using antiserum AII $\times 500$ )

Fig. 2. Class I MHC expression in normal autopsy pancreas. This is an adjacent section to that photographed in Fig. 1. Staining is again seen on endothelial cells. Class I MHC is almost undetectable on endocrine cells using this technique. (Indirect immunoperoxidase using antiserum $\mathrm{AI} \times 500$ )

(RIA UK Ltd., Tyne \& Wear, UK) and finally a 30-min incubation with fluorescein conjugated donkey anti-rabbit immunoglobulins. Again, repeated washings with tris buffered saline were done in between incubations. Double-stained sections were viewed using a Leitz Orthomat microscope. Control pancreases and spleen were tested on all occasions and there were no cross reactions observed between the two steps of these double techniques.

\section{Statistical analysis}

The proportion of insulin containing islets which hyperexpressed Class I MHC was compared to the proportion of insulin deficient islets which exhibited this phenomenon. Statistical significance was assessed using the Chi-squared test.

\section{Results}

\section{Normal autopsy pancreas}

The distribution of Class II MHC in the normal autopsy pancreas, as assessed by the antiserum AII, was the same as that described previously using the antibody TAL-1B5 (Fig.1) [12]. Thus, in the islets only the endothelial cells were stained, while in exocrine tissue occasional ducts were positive but acini were generally negative. There was almost undetectable staining for Class I MHC antigens on islet endocrine cells using the antiserum AI. Endothelial cells and nerve fibres were strongly positive, but the exocrine tissues stained relatively weakly (Fig. 2).

\section{The pancreas in Type 1 diabetes}

Four principal variables were analysed: (1) insulin content of islets, (2) presence or absence of insulitis, (3) presence or absence of aberrant expression of Class II MHC on islet endocrine cells, (4) degree of expression of Class I MHC antigens on islet endocrine cells. Tables 1 and 2 give the results of the analysis of islet staining on 3 consecutive serial sections from each case stained for Class I MHC, insulin and Class II MHC respectively. The degree of expression of Class I MHC on islet endocrine cells and the presence or absence of insulin in an islet could be assessed fairly confidently on single sections of tissue stained for the respective antigens. However, aberrant Class II MHC expression on endocrine cells and the presence of an inflammatory infiltrate could be quite focal within an islet, and the presence of these was liable to be underestimated if only one section from each case was examined. Thus, three cases $[8,12,19]$ were chosen for more detailed study on the basis that blocks were available and that the phenomena under investigation were present. For- 
ty serial sections were cut from one of the several pancreatic blocks available for each case and the middle two sections stained for Class I MHC products and in-

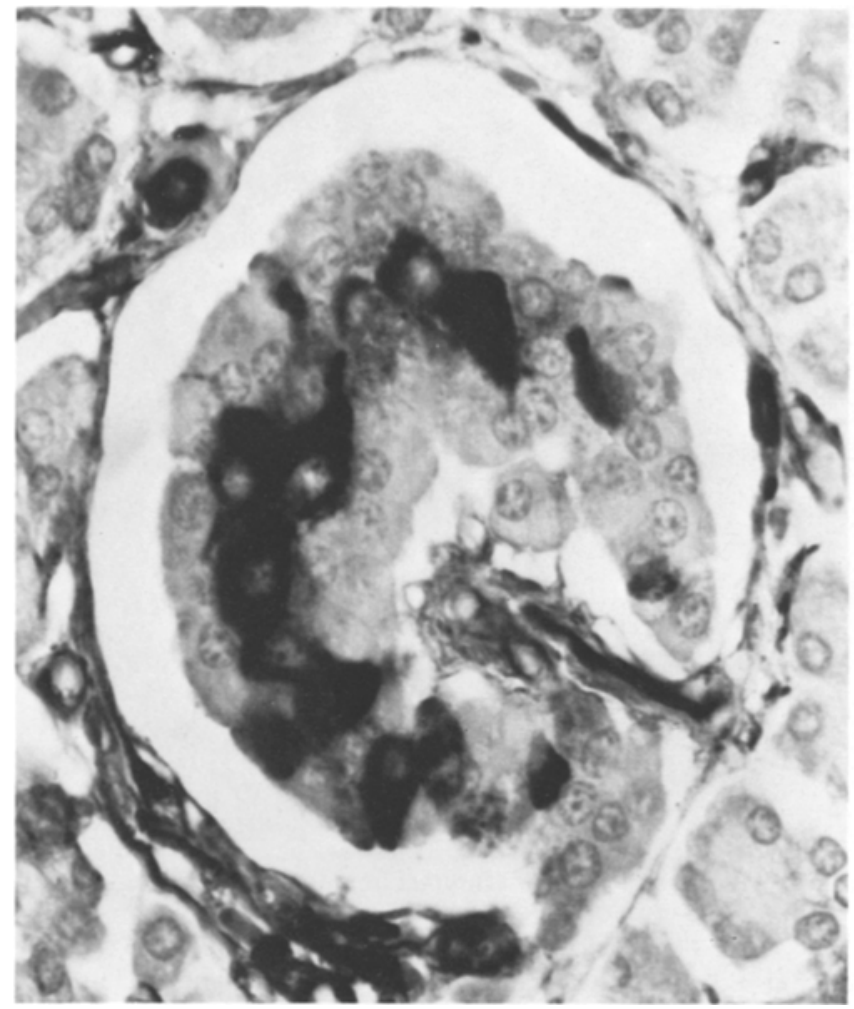

Fig.3. Class II MHC expression on islet endocrine cells in Type 1 diabetes. The positive cells show uniform cytoplasmic staining and lie flanked by negatively staining endocrine cells. An adjacent section showed the presence of B cells in this islet. (Intraperitoneally using antiserum $\mathrm{AII} \times 800$ ) sulin respectively. The remaining sections were stained for Class II MHC products. From this, the presence of focal insulitis, or infrequent aberrant expression of Class II MHC on endocrine cells, could be assessed for any islet identified on the middle two sections. The results of this analysis are given in Table 3.

\section{Aberrant expression of Class II MHC products on islet endocrine cells}

Insulin containing islets were present in all 23 cases of recent onset diabetes and in 8 out of 12 cases where the disease had been present for more than one year. Aberrant expression of Class II MHC on endocrine cells was seen in 21 of the recent onset cases and 6 of the prolonged duration cases (Fig. 3). The maximum duration of diabetes where this phenomenon was observed was 9 years. Endocrine cells expressing Class II MHC were seen in 377 out of 2744 insulin containing islets but not in 6842 insulin deficient islets. Double stains for hormones and Class II MHC confirmed the previous observation that only B cells expressed this antigen (Figs. 4, 5). When 2 adjacent serial sections were stained with AII and UUII, both polyclonal antisera to Class II MHC, the results were identical. As with the previous study using TAL-1B5 [12], the staining for Class II MHC was cytoplasmic (Fig.3).

It is recognised that the detailed results of the cases reported previously [12, Table 1] were not identical to those observed in this study. This was because fresh serial sections were cut for the present study.
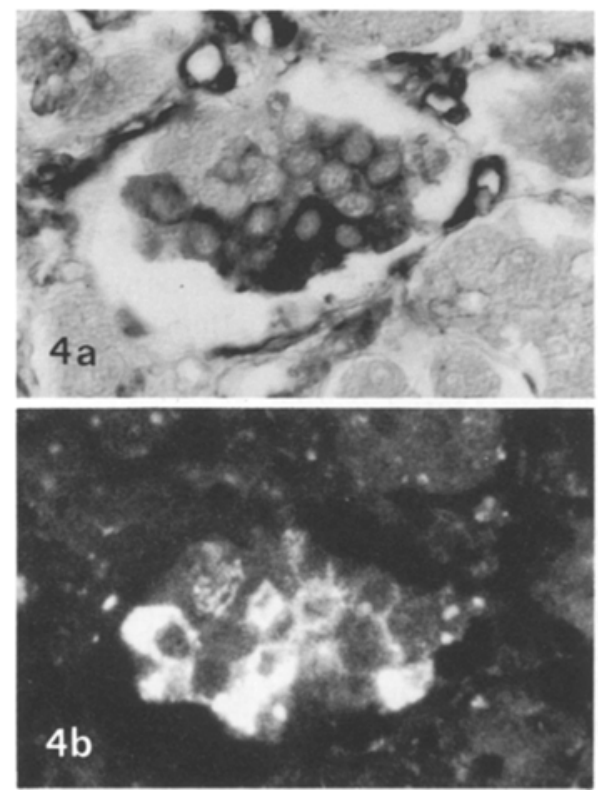

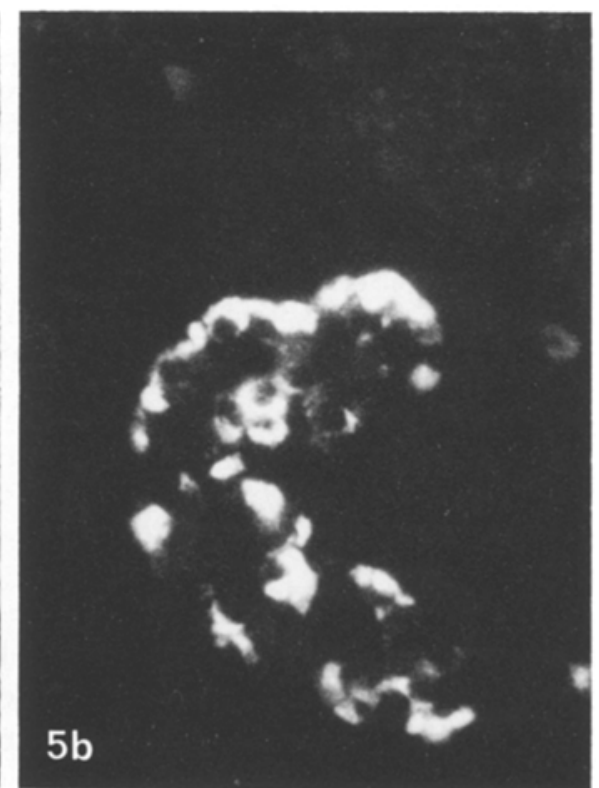

Fig. $4 \mathrm{a}$ and $\mathbf{b}$. The section has been double stained by an immunoperoxidase technique for Class II MHC (a) and by an indirect immunofluorescence technique for insulin (b). Several B cells are present which aberrantly express Class II MHC ( $\times$ 500)

Fig. $5 \mathbf{a}$ and $\mathbf{b}$. The section has been double stained by an immunoperoxidase technique for Class $\mathrm{II} \mathrm{MHC}(\mathrm{a})$ and by an indirect immunofluorescence technique for glucagon (b). Class II MHC positive endocrine cells do not contain glucagon $(\times 500)$ 

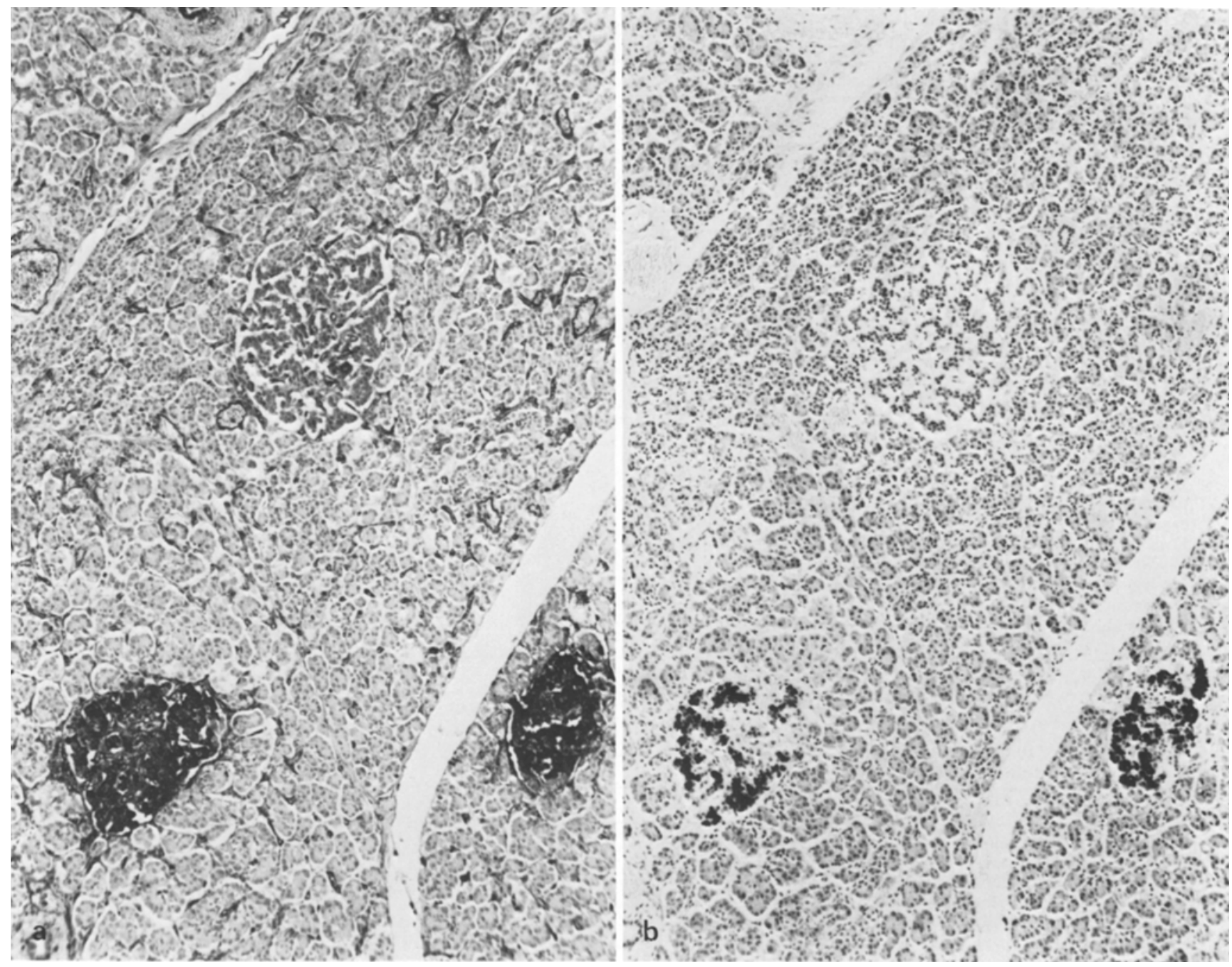

Fig. 6 a There is marked hyperexpression of Class I MHC on the endocrine cells in the two islets at the bottom of the picture. By contrast, the islet at the top of the picture shows markedly diminished expression of this product. b The serial section has been stained for insulin and shows that the islet at the top of the picture is insulin deficient $(\times 70)$

\section{Degree of Class I MHC expression and insulin content of islets}

A striking observation was the very marked degree of hyperexpression of Class I MHC on insulin containing islets (Fig. 6). In islets where this was present, there was not only increased cytoplasmic staining but also considerable accentuation in the region of the plasma membrane of cells. Class I MHC hyperexpression was present in all 31 patients with residual insulin containing islets. Furthermore, it was found in 2517 out of 2744 such islets (92\%) but was only seen in 82 out of 6842 insulin deficient islets $(1 \%, p<0.001$ Chi-squared test) (Table 1). The pattern of staining when two adjacent serial sections were stained with the antisera directed against Class I MHC heavy chain (AI) and beta-2-microglobulin, respectively, was identical. In contrast to the findings with Class II MHC expression, all the endocrine cells in a given insulin containing islet appeared to hyperexpress Class I MHC. This was confirmed by double stains for Class I MHC and the re- spective hormones (Figs. 7, 8). Thus, it appeared that when glucagon secreting A cells and somatostatin secreting D cells were adjacent to B cells in an insulin containing islet in this disease they hyperexpressed Class I MHC, but when they were physically divorced from B cells, in an insulin deficient islet, they ceased to hyperexpress Class I MHC. (The findings with PP cells were not formally assessed, since all the insulin containing islets examined were in the glucagon-rich lobe).

Occasional insulin containing islets in which there was no hyperexpression of Class I MHC were observed in some cases. It was interesting to note that these islets tended to be grouped together in a non-random manner, often within the same pancreatic lobule (Fig.9).

\section{The relevance of the serial section study of "whole" islets}

Comparison between the findings for the 3 cases 8,12 and 19 given in Tables 1 and 3 shows that when 40 serial sections were not done the frequency of insulitis 
Table 1. Insulin content of islets, insulitis, hyperexpression of Class I MHC and aberrant expression of Class II MHC on islet endocrine cells in Type 1 diabetes: detail of cases

\begin{tabular}{|c|c|c|c|c|c|c|c|c|c|c|c|c|c|}
\hline \multirow[t]{3}{*}{ Case } & \multirow[t]{3}{*}{ Age } & \multirow[t]{3}{*}{ Sex } & \multirow{3}{*}{$\begin{array}{l}\text { Duration } \\
\text { of } \\
\text { diabetes }\end{array}$} & \multicolumn{4}{|c|}{ Insulin containing islets (ICI) } & \multicolumn{4}{|c|}{ Insulin deficient islets (IDI) } & \multirow{2}{*}{\multicolumn{2}{|c|}{$\begin{array}{l}\text { Islets with Class II } \\
\text { MHC positive endo- } \\
\text { crine cells }\end{array}$}} \\
\hline & & & & Total & No. with & No. with & No. with & Total & No. with & No. with & No. with & & \\
\hline & & & & & & $\begin{array}{l}\text { pression } \\
\text { of Class I } \\
\text { MHC }\end{array}$ & $\begin{array}{l}\text { expression } \\
\text { of Class II } \\
\text { MHC on en- } \\
\text { docrine cells }\end{array}$ & & Hantis & $\begin{array}{l}\text { pression } \\
\text { of Class I } \\
\text { MHC }\end{array}$ & $\begin{array}{l}\text { expression } \\
\text { of Class II } \\
\text { MHC on en- } \\
\text { docrine cells }\end{array}$ & $\begin{array}{l}\text { Insulitis } \\
\text { present }\end{array}$ & $\begin{array}{l}\text { Insulitis } \\
\text { absent }\end{array}$ \\
\hline
\end{tabular}

\section{Recent onset diabetes}

\begin{tabular}{|c|c|c|c|c|c|c|c|c|c|c|c|c|c|}
\hline 1 & 18 months & $\mathrm{F}$ & $1 w k$ & 116 & 112 & 115 & 9 & 1239 & 8 & 6 & 0 & 9 & 0 \\
\hline 2 & 21 months & $\mathrm{F}$ & 2 wks & 16 & 11 & 16 & 2 & 69 & 1 & 2 & 0 & 2 & 0 \\
\hline 3 & 2 years & M & 2 wks & 19 & 1 & 16 & 0 & 177 & 3 & 7 & 0 & 0 & 0 \\
\hline 4 & 3 years & $\mathrm{F}$ & $6 \mathrm{wks}$ & 88 & 30 & 88 & 4 & 43 & 1 & 3 & 0 & 0 & 4 \\
\hline 5 & 3 years & $\mathbf{M}$ & 4 days & 59 & 17 & 59 & 5 & 292 & 1 & 0 & 0 & 4 & 1 \\
\hline 6 & 3 years & $\mathrm{M}$ & $3 \mathrm{mths}$ & 45 & 6 & 45 & 16 & 100 & 2 & 0 & 0 & 4 & 12 \\
\hline 7 & 5 years & $\mathrm{F}$ & $12 \mathrm{wks}$ & 29 & 2 & 27 & 1 & 21 & 0 & 0 & 0 & 1 & 0 \\
\hline 8 & 6 years & $\mathrm{M}$ & 6 days & 128 & 35 & 128 & 22 & 359 & 6 & 4 & 0 & 20 & 2 \\
\hline 9 & 6 years & $\mathrm{F}$ & few wks & 36 & 4 & 36 & 4 & 79 & 1 & 0 & 0 & 1 & 3 \\
\hline 10 & 7 years & $\mathrm{M}$ & 3 days & 37 & 19 & 37 & 7 & 148 & 6 & 4 & 0 & 7 & 0 \\
\hline 11 & 8 years & $\mathrm{M}$ & few mths & 118 & 2 & 79 & 8 & 69 & 1 & 1 & 0 & 1 & 7 \\
\hline 12 & 10 years & $\mathrm{M}$ & 3 wks & 117 & 0 & 111 & 15 & 150 & 0 & 3 & 0 & 0 & 15 \\
\hline 13 & 11 years & $\mathbf{M}$ & 2 wks & 29 & 0 & 29 & 5 & 13 & 0 & 2 & 0 & 0 & 5 \\
\hline 14 & 12 years & $\mathrm{F}$ & 3 wks & 36 & 5 & 36 & 1 & 37 & 6 & 0 & 0 & 0 & 1 \\
\hline 15 & 14 years & $\mathrm{F}$ & few wks & 135 & 61 & 134 & 10 & 353 & 7 & 1 & 0 & 10 & 0 \\
\hline 16 & 16 years & $\mathbf{M}$ & few wks & 18 & 4 & 16 & 4 & 29 & 0 & 1 & 0 & 4 & 0 \\
\hline 17 & 17 years & $\mathbf{M}$ & 2 days & 377 & 226 & 369 & 28 & 211 & 6 & 2 & 0 & 23 & 5 \\
\hline 18 & 17 years & $\mathbf{M}$ & $1 \mathrm{wk}$ & 358 & 117 & 357 & 84 & 217 & 28 & 36 & 0 & 40 & 44 \\
\hline 19 & 21 years & $\mathbf{M}$ & 3 wks & 329 & 35 & 325 & 113 & 278 & 1 & 10 & 0 & 24 & 89 \\
\hline
\end{tabular}

Recent onset polyendocrine diabetes

\begin{tabular}{|c|c|c|c|c|c|c|c|c|c|c|c|c|c|}
\hline 20 & 8 years & $\mathrm{F}$ & 3 weeks & 114 & 5 & 80 & 0 & 99 & 0 & 0 & 0 & 0 & 0 \\
\hline 21 & 13 years & $F$ & 2 months & 101 & 5 & 101 & 1 & 26 & 0 & 0 & 0 & 0 & 1 \\
\hline 22 & 18 years & $\mathrm{F}$ & few weeks & 185 & 7 & 140 & 8 & 18 & 0 & 0 & 0 & 0 & 8 \\
\hline 23 & 18 years & $\mathbf{M}$ & few weeks & 61 & 4 & 54 & 4 & 35 & 0 & 0 & 0 & 1 & 3 \\
\hline
\end{tabular}

Prolonged duration diabetes

\begin{tabular}{|c|c|c|c|c|c|c|c|c|c|c|c|c|c|}
\hline 24 & 5 years & $\mathrm{F}$ & 15 months & 3 & 0 & 3 & 0 & 142 & 0 & 0 & 0 & 0 & 0 \\
\hline 25 & 15 years & $\mathrm{F}$ & 2 years & 73 & 0 & 45 & 4 & 63 & 0 & 0 & 0 & 0 & 4 \\
\hline 26 & 3 years & $\mathbf{F}$ & 2 years & 0 & 1 & 0 & 0 & 278 & 0 & 0 & 0 & 0 & 0 \\
\hline 27 & 9 years & $\mathrm{F}$ & 2 years & 3 & 0 & 3 & 2 & 26 & 0 & 0 & 0 & 1 & 1 \\
\hline 28 & 10 years & $F$ & 2 years & 0 & 0 & 0 & 0 & 50 & 0 & 0 & 0 & 0 & 0 \\
\hline 29 & 5 years & M & 2 years & 0 & 0 & 0 & 0 & 252 & 0 & 0 & 0 & 0 & 0 \\
\hline 30 & 16 years & $F$ & 4 years & 12 & 0 & 8 & 2 & 142 & 0 & 0 & 0 & 0 & 2 \\
\hline 31 & 8 years & $\mathrm{F}$ & 5 years & 12 & 6 & 12 & 10 & 550 & 1 & 0 & 0 & 5 & 5 \\
\hline 32 & 11 years & $\mathbf{M}$ & 6 years & 32 & 1 & 32 & 6 & 342 & 0 & 0 & 0 & 0 & 6 \\
\hline 33 & 18 years & $\mathrm{F}$ & 6 years & 23 & 0 & 2 & 0 & 306 & 0 & 0 & 0 & 0 & 0 \\
\hline 34 & 20 years & $\mathrm{M}$ & 6 years & 0 & 0 & 0 & 0 & 449 & 0 & 0 & 0 & 0 & 0 \\
\hline 35 & 18 years & $\mathrm{F}$ & 9 years & 35 & 0 & 14 & 2 & 180 & 0 & 0 & 0 & 0 & 2 \\
\hline Tota & & & & 2744 & 716 & 2517 & 377 & 6842 & 79 & 82 & 0 & 157 & 220 \\
\hline
\end{tabular}

and aberrant expression of Class II MHC on islets was seriously underestimated. Thus, when only a single section of each block was stained in these 3 cases $12 \%$ of insulin containing islets were affected by insulitis and insulitis was not seen in case 12 (Table 1). The "whole" islet study of a single representative block of each case showed that $44 \%$ of insulin containing islets were inflammed and insulitis was in fact present in case 12. Similarly, in Table $126 \%$ of insulin containing islets from these cases were seen to contain B cells expressing class II MHC, but this figure rose to $67 \%$ when "whole" islets were examined. However, comparison between the results in Table 1 and Table 3 shows that the frequency of hyperexpression of Class I MHC by insulin containing islets could be accurately estimated from a single section. The explanation for the disparity is that insulitis and aberrant expression of
Class II MHC can be quite focal within an islet and that maximum accuracy of the frequency of these phenomena in Type 1 diabetes can only be obtained by study of "whole" islets.

\section{The relationship between Class I MHC hyperexpression} and aberrant expression of Class II MHC

Table 3 shows that insulin containing islets could be found which did not hyperexpress Class I MHC. These islets showed no evidence of aberrant expression of Class II MHC. It also shows that $27 \%$ of the islets where there was hyperexpression of Class I MHC had no evidence of Class II MHC expression on B cells. The remaining islets exhibited both phenomena. Thus, no islets were seen where the only abnormality of 


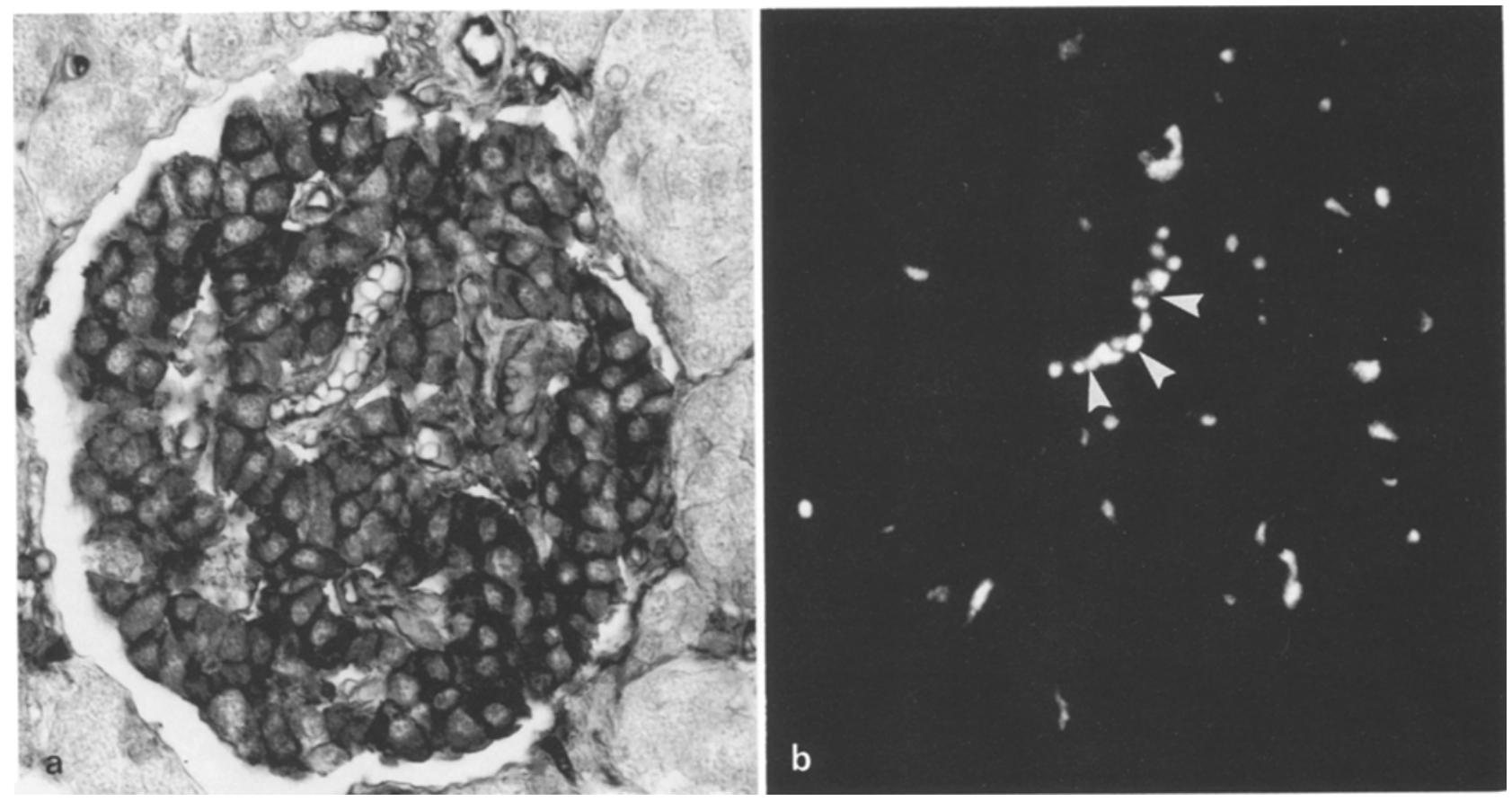

Fig. 7. The section has been double stained by an indirect immunoperoxidase technique for Class I MHC (a) and by an indirect immunofluorescence technique for insulin (b). Note the relatively low number of $\mathrm{B}$ cells compared to the number of endocrine cells which are hyperexpressing Class I MHC. Arrow heads mark autofluorescing erythrocytes $(\times 500)$

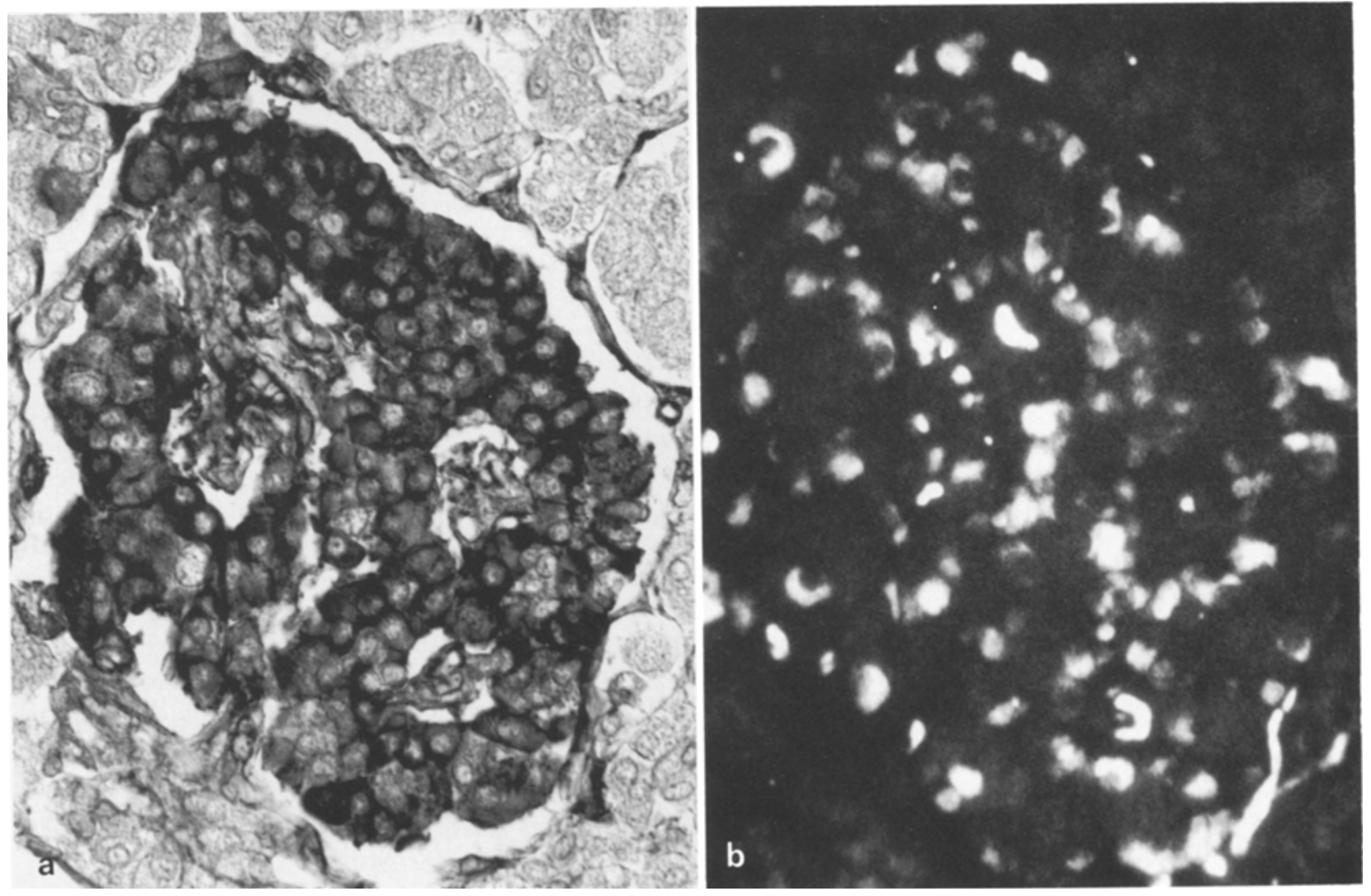

Fig.8. The section has been double stained by an indirect immunoperoxidase technique for Class I MHC (a) and by an indirect immunofluorescence technique for glucagon (b). A cells hyperexpress Class I MHC in this islet $(\times 500)$ 


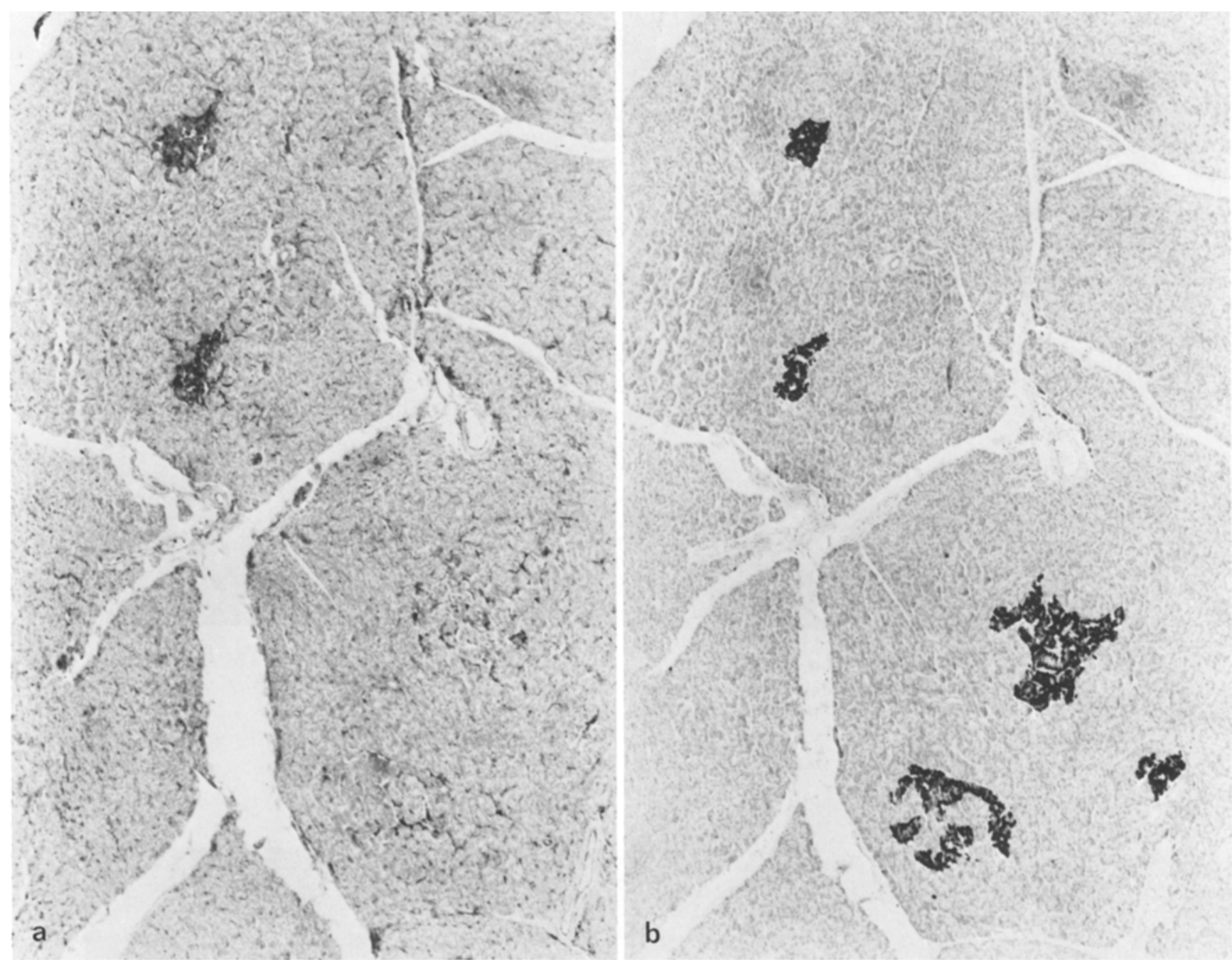

Fig.9 a There is hyperexpression of Class I MHC by two islets in the top left of the picture. [Indirect immunoperoxidase using antiserum AI $(\times 500)$ ]. b The serial section shows insulin containing islets in the pancreatic lobule in the bottom right of the picture which do not hyperexpress Class I MHC [indirect immunoperoxidase for insulin $(\times 500)$ ]

MHC expression was the presence of Class II molecules on B cells.

\section{The relationship between insulitis and abnormalities of $M H C$ expression}

All insulin containing islets affected by insulitis hyperexpressed Class I MHC. Interestingly, such hyperexpression was not necessarily found in inflamed insulin deficient islets. However, many of the islets in which hyperexpression of Class I MHC was observed were not affected by insulitis (Table 3 ).

In the serial section study of "whole" islets half of the islets in which aberrant expression of Class II MHC was seen had no evidence of insulitis. In case 8 (Table 3) it was noted that insulin containing islets could be found where there was insulitis but no evidence of Class II MHC expression on endocrine cells.

\section{Polyendocrine diabetes}

While there were too few cases to draw firm conclusions, the results in Table 2 suggest that when patients with recent-onset polyendocrine diabetes were compared to the remainder of the patients with Type 1 diabetes of short duration not only were fewer insulin containing islets inflamed, but also only $2.8 \%$ of insulin containing islets had aberrant Class II MHC expression compared to $16 \%$ for the others. Similarly, fewer insulin containing islets hyperexpressed Class I MHC in the recent onset polyendocrine diabetic patients.

Class I and II MHC expression in pancreatic diseases other than Type 1 diabetes

While there was significant pancreatic inflammation in 13 of the bone marrow grafted patients (two of whom 
Table 2. Insulin content of islets, insulitis, aberrant expression of Class II MHC and hyperexpression of Class I MHC on islet endocrine cells in Type 1 diabetes: summary of cases

\begin{tabular}{|c|c|c|c|}
\hline Number of & $\begin{array}{l}\text { Non polyen- } \\
\text { docrine recent } \\
\text { onset diabetes }\end{array}$ & $\begin{array}{l}\text { Polyendocrine } \\
\text { recent onset } \\
\text { diabetes }\end{array}$ & $\begin{array}{l}\text { Prolonged du- } \\
\text { ration diabe- } \\
\text { tes (more than } \\
1 \text { year) }\end{array}$ \\
\hline Cases & 19 & 4 & 12 \\
\hline Cases with ICI & 19 & 4 & 8 \\
\hline ICI & 2090 & 461 & 193 \\
\hline IDI & 3884 & 178 & 2780 \\
\hline Cases with insulitis & 17 & 4 & 3 \\
\hline $\begin{array}{l}\text { Cases with aberrant } \\
\text { expression of } \\
\text { Class II MHC } \\
\text { on ICI }\end{array}$ & 18 & 3 & 6 \\
\hline $\begin{array}{l}\text { ICI with aberrant } \\
\text { expression of } \\
\text { Class II MHC }\end{array}$ & 338 & 13 & 26 \\
\hline $\begin{array}{l}\text { IDI with aberrant } \\
\text { expression of } \\
\text { Class II MHC }\end{array}$ & 0 & 0 & 0 \\
\hline ICI with insulitis & 687 & 21 & 8 \\
\hline $\begin{array}{l}\text { Islets with aberrant } \\
\text { expression of } \\
\text { Class II MHC } \\
\text { and insulitis }\end{array}$ & 150 & 1 & 6 \\
\hline $\begin{array}{l}\text { Islets with aberrant } \\
\text { expression of } \\
\text { Class II MHC but } \\
\text { no insulitis }\end{array}$ & 188 & 12 & 20 \\
\hline $\begin{array}{l}\text { Cases with hyperex- } \\
\text { pression of Class I } \\
\text { MHC on ICI }\end{array}$ & 19 & 4 & 8 \\
\hline $\begin{array}{l}\text { ICI which hyperex- } \\
\text { press Class I MHC }\end{array}$ & $\begin{array}{l}2023 \\
(97 \% \text { of ICI) }\end{array}$ & $\begin{array}{l}375 \\
(81 \% \text { of ICI) }\end{array}$ & $\begin{array}{l}119 \\
(61 \% \text { of ICI })\end{array}$ \\
\hline $\begin{array}{l}\text { IDI which hyperex- } \\
\text { press Class I MHC }\end{array}$ & $\begin{array}{c}82 \\
(2 \% \text { of } \mathrm{IDI})\end{array}$ & 0 & 0 \\
\hline $\begin{array}{l}\text { Islets with aberrant } \\
\text { expression of } \\
\text { Class II MHC but } \\
\text { no hyperexpression } \\
\text { of Class I MHC }\end{array}$ & 0 & 0 & 0 \\
\hline
\end{tabular}

$\mathrm{ICI}=$ insulin containing islets; IDI $=$ insulin deficient islets

had no clinical evidence of graft-versus-host disease), the inflammatory infiltrate was diffuse throughout the pancreas with no evidence of specific insulitis or endocrine cell damage. Marked endocrine cell necrosis affecting A cells as well as B cells was seen in 4 of the 12 neonates who had died of culture proven Coxsackie $B$ viral myocarditis. In 3 of these 4 there was a prominent insulitis characterised by lymphocytes and eosinophils.

No evidence of aberrant expression of Class II MHC was seen on endocrine cells in the pancreases of the 20 bone marrow grafted patients, the five resections for chronic pancreatitis, the 10 cases of cystic fibrosis, the 10 cases of Type 2 diabetes and the 12 cases with Coxsackie B viral infection. In pancreases where inflammation was present there was a moderate level of
Table 3. Insulitis, aberrant expression of Class II MHC and hyperexpression of Class I MHC on islet endocrine cells of insulin containing islets: results of study of 40 serial sections on 3 cases

\begin{tabular}{lllc}
\hline Number of & Case 19 & Case 8 & Case 12 \\
\hline ICI counted & 50 & 40 & 40 \\
ICI with insulitis & 16 & 39 & 2 \\
$\begin{array}{l}\text { ICI with aberrant expression } \\
\text { of Class II MHC }\end{array}$ & 44 & 26 & 18 \\
$\begin{array}{l}\text { ICI with aberrant expression } \\
\text { of Class II MHC and insulitis }\end{array}$ & 16 & 26 & 2 \\
$\begin{array}{l}\text { ICI with aberrant expression } \\
\text { of Class II MHC and no insu- }\end{array}$ & 28 & 0 & 16 \\
litis & & & \\
$\begin{array}{l}\text { ICI with hyperexpression of } \\
\text { Class I MHC }\end{array}$ & 48 & 40 & 32 \\
$\begin{array}{l}\text { ICI with hyperexpression of } \\
\text { Class I MHC but no aberrant } \\
\text { expression of Class II MHC }\end{array}$ & 4 & 14 & 14 \\
$\begin{array}{l}\text { ICI with no hyperexpression } \\
\text { of Class I MHC but presence } \\
\text { of aberrant expression of }\end{array}$ & 0 & 0 & 0 \\
$\begin{array}{l}\text { Class II MHC } \\
\text { ICI with insulitis and hyper- } \\
\text { expression of Class I MHC }\end{array}$ & 16 & 39 & 2 \\
$\begin{array}{l}\text { ICI = insulin containing islets } \\
\text { If }\end{array}$ & & \\
\hline
\end{tabular}

staining for Class II MHC on the exocrine pancreas. In the inflamed pancreases there was also considerable hyperexpression of Class I MHC diffusely throughout the pancreas. This was most marked in cases of cystic fibrosis. Usually, however, the degree of expression of Class I MHC on islets was less than that observed in exocrine tissue. In no disease did the degree of expression of Class I MHC on islets match that seen on insulin containing islets from patients with Type 1 diabetes.

\section{Discussion}

Evidence is presented here that aberrant expression of Class II MHC, confined to B cells, and hyperexpression of Class I MHC by all the endocrine cells in insulin containing islets are as pathognomonic of Type 1 diabetes as are the presence of insulitis and loss of $B$ cells.

Pancreatic diseases in which there was a marked chronic inflammatory cell infiltrate were chosen as controls because in them release of immune modulators known to affect pancreatic endocrine cell MHC expression might be expected to be present [18-20]. While considerable expression of Class I and II MHC products was seen on ducts and acini in these diseases the phenomena of $\mathrm{MHC}$ expression seen on endocrine cells in Type 1 diabetes were not present. Aberrant expression of Class II MHC has been observed in a number of organs in graft-versus-host disease [21, 22], but was absent in the endocrine pancreas in patients with this disease in the present study. Class II MHC expression on B cells in Type 1 diabetes is unlikely to 


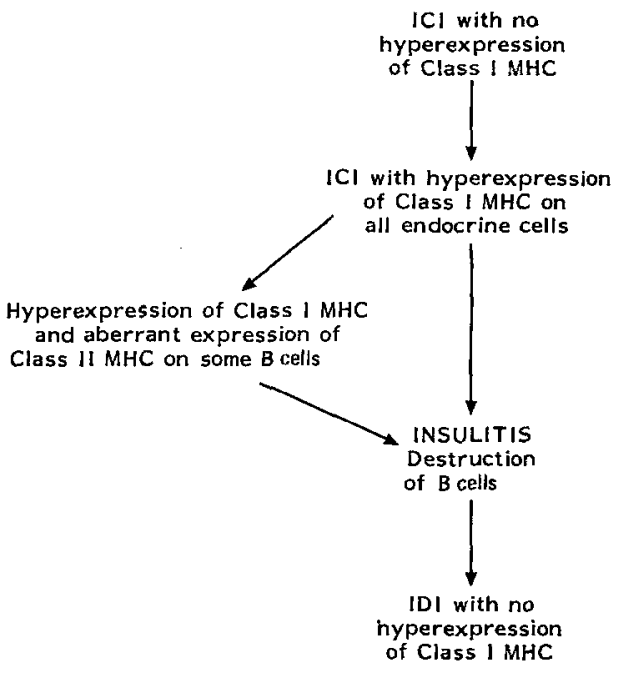

$[C \mid=$ insulin containing islet

$|D|=$ insulin deficient islet

Fig. 10. Proposed sequence of events within individual islets in Type 1 diabetes

be the result of incipient death of these cells since such expression was not observed in the 4 cases of Coxsackie $B$ viral pancreatitis where endocrine cell necrosis was present. Equally, the abnormalities of MHC expression are not thought to be the result of the metabolic derangements of diabetes since they were not seen in the pancreases of patients with Type 2 diabetes or of the two young patients with cystic fibrosis who were diabetic.

If it is accepted that insulitis, destruction of B cells, expression of Class II MHC by B cells and hyperexpression of Class I MHC by insulin containing islets are the characteristic lesions of Type 1 diabetes, in what sequence do they occur within a given islet? It is recognised that any answers to this question are liable to be speculative since the earliest opportunity to observe these changes in the human pancreas is when approximately $70 \%$ of the $\mathrm{B}$ cells have been destroyed. However, there is merit in the argument that the prediabetic pancreas may be similar qualitatively to the pancreas at clinical presentation [12].

Based on the present material, there is evidence to suggest that within an individual islet hyperexpression of Class I MHC on all endocrine cells in an insulin containing islet precedes aberrant expression of Class II MHC on B cells. From Table 3 it can be seen that, while the majority of islets studied exhibited both abnormalities of MHC expression, islets were present where the only abnormality was hyperexpression of Class I MHC; however, no islets were seen where the only abnormality was aberrant expression of Class II MHC on B cells.

Similar arguments can be put forward to suggest that Class I MHC hyperexpression precedes insulitis. Approximately half of the islets where this hyperexpression was seen had no evidence of insulitis, but all inflamed insulin containing islets hyperexpressed Class I MHC (Table 3). Equally, inflamed insulin deficient islets could be found in which there was no hyperexpression of Class I MHC on A and D cells.

It has previously been argued that within a given islet aberrant expression of Class II MHC on B cells precedes insulitis [12]. In the present study of "whole" islets (Table 3) half of the 88 islets in which B cell Class II MHC expression was seen had no evidence of insulitis. The absence of such expression on B cells in pancreatic inflammatory diseases and the failure of interferon-gamma and other inflammatory mediators to selectively induce Class II MHC expression on B cells but not other pancreatic endocrine cells in vitro [18-20] are in keeping with this conclusion.

The proposed sequence of events within an individual islet in Type 1 diabetes is therefore as follows (Fig.10). The earliest demonstrable abnormality may be hyperexpression of Class I MHC. This may be followed either directly by insulitis [inflamed islets could be found in Case 8 (Table 3) which did not have aberrant expression of Class II MHC] or by aberrant expression of Class II MHC on some B cells and then by insulitis. B cells are killed in this inflammatory process, leaving an islet consisting of $\mathrm{A}, \mathrm{D}$ and PP cells which no longer hyperexpress Class I MHC.

The BB rat has been used as a model of Type 1 diabetes and in this animal aberrant expression of Class II MHC by B cells is thought to be a late event which follows insulitis within a given islet [23]. In keeping with this observation has been the demonstration that interferon-gamma caused isolated B cells from pre-diabetic $\mathrm{BB} / \mathrm{E}$ rats to express Class II MHC in vitro [24]. B cells from normal Wistar rats did not exhibit this phenomenon in culture. This suggests that there may be a genetic abnormality of control of Class II MHC expression by $\mathrm{B}$ cells in these animals. A similar genetic abnormality of control of Class II MHC expression by $B$ cells may be crucial in the pathogenesis of Type 1 diabetes in man. In the human pancreatic isograft study described by Sibley et al. [25], B cells genetically identical to those of the diabetic twins were destroyed within weeks of transplant by an islet infiltrate which included $T$ lymphocytes. These inflammatory cells would be expected to be secreting interferon-gamma (immunosuppression was not given in 3 of the 4 patients studied). In spite of this, Class II MHC expression was not seen in B cells in the transplanted pancreases. This suggests that interferon-gamma may not be able to cause human B cells to express Class II MHC even when they are genetically identical to those of a patient with Type 1 diabetes.

If these abnormalities of islet MHC expression in Type 1 diabetes are not the result of islet inflammation, what is their cause? The intriguing aspect of the phenomenon of hyperexpression of Class I MHC in insulin containing islets was that A and D cells in these islets also hyperexpressed these molecules. One possible 
explanation for this finding would be that the B cells in islets in which Class I hyperexpression was observed were secreting a substance which had a paracrine effect on the adjacent $A$ and $D$ cells, causing them also to hyperexpress Class I MHC. Candidates for this role might include interferon-alpha and -beta. Both these interferons have been shown to cause hyperexpression of Class I MHC on pancreatic endocrine cells in vitro [18]. A common stimulus for release of these substances from epithelial and connective tissue cells is viral infection. A B-cell specific, non-cytopathic viral infection could also be a possible candidate for causing aberrant Class II MHC expression by these cells in a genetically predisposed host. Recently it has been shown that rat astrocytes expressed Class II MHC products in vitro following non-infective interaction with a murine neurotropic coronavirus [26].

Induction of autoimmunity in Type 1 diabetes could be a "multistep" process in which the key event, but not necessarily the first event, is aberrant expression of Class II MHC by B cells.

Acknowledgements. Sincere thanks are expressed to Drs. J.J.Neefjes and L. Klareskog for the gifts of the antisera to MHC products. Professor R.O.C. Kaschula (Cape Town) and Professor G.E.Sale (Seattle) kindly allowed us to examine pancreases from cases of Coxsackie B viral myocarditis and graft-versus-host disease respectively. M.A.F. was supported by a grant from the British Diabetic Association. Ms. M.Habbick kindly typed the manuscript.

\section{References}

1. Bottazzo GF (1984) Beta-Cell damage in diabetic insulitis: are we approaching a solution? Diabetologia 26: 241-249

2. Gepts W (1965) Pathologic anatomy of the pancreas in juvenile diabetes mellitus. Diabetes 14: 619-633

3. Foulis AK, Liddle CN, Farquharson MA, Richmond JA, Weir RS (1986) The histopathology of the pancreas in Type 1 (insulin-dependent) diabetes mellitus: a 25-year review of deaths in patients unter 20 years of age in the United Kingdom. Diabetologia 29: $267-274$

4. Wolf E, Spencer KM, Cudworth AG (1983) The genetic susceptibility to Type 1 (insulin-dependent) diabetes: analysis of the HLA-DR association. Diabetologia 24: 224-230

5. Bottazzo GF, Pujol-Borrell R, Hanafusa T, Feldmann M (1983) Role of aberrant HLA-DR expression and antigen presentation in induction of endocrine autoimmunity. The Lancet 2 1115-1118

6. Alejandro R, Shienvold FL, Hajek SV, Ryan U, Miller J, Mintz DH (1982) Immunocytochemical localisation of HLA-DR in human islets of Langerhans. Diabetes 31 [Suppl 4]: 17-22

7. Natali PG, DeMartino CD, Quaranta V, Nicotra MR, Frezza F, Pellegrino MA, Ferrone S (1981) Expression of Ia-like antigens in normal human non-lymphoid tissues. Transplantation 31 : $75-78$

8. Gepts W, De Mey J (1978) Islet cell survival determined by morphology - an immunocytochemical study of the islets of Langerhans in juvenile diabetes mellitus. Diabetes 27 [Suppl 1]: 251-261

9. Bottazzo GF, Dean BM, McNally JM, MacKay EH, Swift PGF, Gamble DR (1985) In situ characterisation of autoimmune phenomena and expression of HLA molecules in the pancreas in diabetic insulitis. $\mathrm{N}$ Engl J Med 313: 353-360

10. Adams TE, Bodmer G, Bodmer WF (1983) Production and characterisation of monoclonal antibodies recognising the alpha chain subunits of human Ia alloantigens. Immunology 50 : 613-624

11. Epenetos AA, Bobrow LG, Adams TE, Collins CM, Isaacson PG, Bodmer WF (1985) A monoclonal antibody that detects HLA- region antigen in routinely fixed, wax embedded sections of normal and neoplastic lymphoid tissues. J Clin Pathol 38: 12-17

12. Foulis AK, Farquharson MA (1986) Aberrant expression of HLA-DR antigens by insulin containing beta cells in recent onset Type 1 (insulin-dependent) diabetes mellitus. Diabetes 35: 1215-1224

13. Neefjes JJ, Doxiadis I, Stam NJ, Beckers CJ, Ploegh HL (1986) An analysis of Class I antigens of man and other species by one dimensional IEF and immunoblotting. Immunogenetics 23: 164-171

14. Alberts B, Bray D, Lewis J, Raff M, Roberts K, Watson JD (1983) Molecular biology of the cell, Garland Publishing, New York, pp 1000-1007

15. Parham P, Barnstable CJ, Bodmer WF (1979) Use of a monoclonal antibody (W6/32) in structural studies of HLA-A,B,C antigens. J Immunol 123: 342-349

16. Neefjes JJ, Hensen EJ, De Kroon TIP, Ploegh HL (1986) A biochemical characterisation of feline MHC products: unusually high expression of Class II antigens on peripheral blood lymphocytes. Immunogenetics $23: 341-347$

17. Klareskog L, Trägardh L, Lindblom JB, Peterson PA (1978) Reactivity of a rabbit antiserum against highly purified HLA-DR antigens. Scand I Immunol 7: 199-208

18. Pujol-Borrell R, Todd I, Doshi M, Gray D, Feldmann M, Bottazzo GF (1986) Differential expression and regulation of MHC products in the endocrine and exocrine cells of the human pancreas. Clin Exp Immunol 65: 128-139

19. Campbell IL, Bizilj K, Colman PG, Tuch BE, Harrison LC (1986) Interferon-gamma induces the expression of HLA-A,B,C but not HLA-DR on human pancreatic beta cells. J Clin Endocrin Metab 62: 1101-1109

20. Pujol-Borrell R, Todd I, Doshi M, Bottazzo GF, Sutton R, Gray D, Adolf GR, Feldmann M (1987) HLA class II induction in human islet cells by interferon-yplus tumour necrosis factor or lymphotoxin. Nature 326: 304-306

21. Lampert IA, Janossy G, Suitters AJ, Bofill M, Palmer S, GordonSmith E, Prentice HG, Thomas JA (1982) Immunological analysis of the skin in graft-versus-host disease. Clin Exp Immunol 50: $123-131$

22. Takacs L, Szende B, Rot A, Diamanstein T (1985) Expression of MHC Class II antigens on bile duct epithelium in experimental graft-versus-host disease. Clin Exp Immunol 60: 449-456

23. Dean BM, Walker R, Bone AJ, Baird JD, Cooke A (1985) Prediabetes in the spontaneously diabetic $\mathrm{BB} / \mathrm{E}$ rat: lymphocyte subpopulations in the pancreatic infiltrate and expression of rat MHC Class II molecules in endocrine cells. Diabetologia 28 : 464-466

24. Walker R, Cooke A, Bone AJ, van der Meide P, Baird JD (1986) Induction of Class II MHC antigens in vitro on pancreatic $B$ cells isolated from BB/E rats. Diabetologia 29: 749-751

25. Sibley RK, Sutherland DER, Goetz F, Michael AF (1985) Recurrent diabetes mellitus in the pancreas iso- and allograft. A light and electron microscopic and immunohistochemical analysis of four cases. Lab Invest 53:132-144

26. Massa PT, Dörries R, Meulen V (1986) Viral particles induce Ia antigen expression on astrocytes. Nature $320: 543-546$

Received: 9 December 1986

and in revised form: 16 March 1987

Dr. A. K. Foulis

Department of Pathology

Royal Infirmary

Glasgow G4 OSF

UK 